\title{
Trabalho, precarização e migração: recrutamento de haitianos na Amazônia acreana pela agroindústria brasileira
}

\section{Work, casualization and migration: recruitment of haitians in the acrean Amazon by agroindustry Brazilian}

Letícia Helena Mamed - Doutoranda em Sociologia na Universidade Estadual de Campinas (UNICAMP). Professora do Centro de Filosofia e Ciências Humanas da Universidade Federal do Acre (CFCH-UFAC). E-mail: leticiamamed@gmail.com.

Eurenice Oliveira de Lima - Doutora em Sociologia pela Universidade Estadual de Campinas (UNICAMP). Professora do Centro de Filosofia e Ciências Humanas da Universidade Federal do Acre (CFCH-UFAC). E-mail: prof.nice@yahoo.com.

\section{Resumo}

Este artigo discute os principais aspectos estruturais do processo de constituição do recente movimento internacional de haitianos pela Amazônia Sul Ocidental (estado do Acre), parcela expressiva dos imigrantes do início do século XXI, que sem condições de reprodução social digna na terra natal são aliciados por redes de tráfico de pessoas e coiotagem, e transportados até o Brasil. Desde 2010, eles são recebidos e preparados como força de trabalho pelo Estado brasileiro, ação diretamente articulada ao posterior recrutamento deles pela agroindústria do Centro-Sul do país. À luz do método dialético, na perspectiva crítica do trabalho, o objetivo primordial é compreender o significado sociológico do trânsito internacional desses trabalhadores precarizados, pretendendo situá-lo no terreno concreto do desenvolvimento do capital e suas desigualdades internacionais e regionais. Os procedimentos de investigação incorporam a pesquisa bibliográfica, documental e de campo, e a utilização de indicadores qualitativos e quantitativos do mundo do trabalho.

\section{Palavras-chave}

Trabalho. Precarização. Migração haitiana. Agroindústria brasileira.

\begin{abstract}
This work discusses the main structural aspects of the formation process of the recent international movement of Haitians by the South Western Amazon (Acre), they are a significant portion of immigrants of the early twenty-first century, that without decent social reproduction conditions in the homeland, they are seduced by trafficking networks of people and transported to Brazil. They are received and prepared as workforce by Brazil since 2010; is a directly coordinated action to further their recruitment by the agroindustry of the Central South of the country. Through the dialectical method and critical perspective of this study, the primary objective is to understand the sociological meaning of the international transit of these precarious workers, intending to place it concretely in the development of capital and its international and regional inequalities. Vetting procedures cover bibliographic research, documentary and field, and the use of qualitative and quantitative indicators of the work world.
\end{abstract}

\section{Keywords}

Work. Casualization. Haitian migration. Brazilian agroindustry. 


\section{INTRODUÇÃO}

A partir das mudanças advindas com o processo de reestruturação produtiva, na transição entre as décadas de 1970 e 1980 (ALVES, 2000; HARVEY, 2002), sucedidas pelas novas modalidades de mobilidade do capital e da força de trabalho em diferentes partes do mundo (CHOSSUDVSKY, 2003; SASSEN, 2011), os debates sobre movimento de trabalhadores e migração nacional e internacional têm ocupado lugar de destaque no contexto da mundialização do capital (CHESNAIS, 1996), notadamente após a eclosão da crise mundial em 2007-2008.

Diversas áreas do saber têm contribuído para o estudo desse tema, explorando aspectos teóricos e realizando estudos empíricos que enaltecem a importância da compreensão do fenômeno, ao mesmo tempo em que revelam sua diversidade. Participando desse debate, o Grupo de Pesquisa Mundos do Trabalho na Amazônia (GPMTA), do Centro de Filosofia e Ciências Humanas $(\mathrm{CFCH})$ da Universidade Federal do Acre (UFAC), há três anos vem desenvolvendo pesquisa com objetivo de examinar, à luz do referencial teórico e metodológico do marxismo, sob a perspectiva crítica do trabalho, o fenômeno do fluxo internacional de imigrantes caribenhos (haitianos, principalmente) e africanos (senegaleses, especialmente), na região da Amazônia Sul Ocidental ${ }^{1}$, na tríplice fronteira entre o Brasil, Peru e Bolívia, por onde ingressam pelo território do estado do Acre, para tentar uma nova vida em solo brasileiro.

Em fluxo constante e crescente em busca do "sonho brasileiro", estimase que de dezembro de 2010 a dezembro de 2014 já passaram pela fronteira do estado do Acre mais de 30 mil imigrantes interessados em seguir para as regiões Sul, Sudeste e Centro-Oeste do país. Na cidade de Rio Branco, capital do Acre, estes são recebidos e abrigados em acampamento estruturado pelo poder público, até a obtenção de documentação e de alguma oportunidade de trabalho no Brasil. A equipe de pesquisa vem acompanhando o dia a dia desse acampamento, onde se desenvolveu um complexo de serviços de acolhimento, atendimento e encaminhamento dos imigrantes, que atualmente está no seu oitavo endereço físico e no quarto ano de existência. Paralelamente, as ações de pesquisa também envolvem um amplo levantamento bibliográfico e documental sobre o tema, além da realização de entrevistas com os agentes envolvidos na questão, como os imigrantes, os representantes do poder público e os profissionais encarregados das ações de acolhimento e orientação destinadas a eles e à comunidade em geral.

\footnotetext{
Refere-se a uma sub-região da Amazônia Legal que corresponde ao sul e sudoeste do estado do Amazonas e aos estados do Acre e de Rondônia.
} 
Neste artigo são apresentados os resultados da pesquisa em curso, consolidados até dezembro de 2014, demarcados por dois eixos: (1) os condicionamentos históricos, econômicos e sociais do movimento internacional de trabalhadores haitianos pela Amazônia Sul-Ocidental (estado do Acre); (2) as principais formas de inserção deles na sociedade brasileira, considerando a condição de vulnerabilidade social por eles apresentada e o direcionamento dessa força de trabalho para o Centro-Sul do país, após o recrutamento realizado pelas empresas da agroindústria.

\section{AS VEIAS ABERTAS DO HAITI: DE COLÔNIA MAIS RICA A PAÍS MAIS POBRE DAS AMÉRICAS}

De acordo com a morfologia social do trabalho no capitalismo contemporâneo (ANTUNES, 2006, 2008, 2013), e conforme o quadro atual de imigrações internacionais com referência ao Brasil (BAENINGER; ANTICO, 1996; PATARRA, 2006), é importante considerar que na década de 1980 teve início um movimento migratório com características diferenciadas em relação aos fluxos sucedidos entre o final do século XIX e início do XX, especialmente provenientes da Europa. Nas últimas três décadas, o ingresso de estrangeiros no Brasil tem sido marcado principalmente por grupos oriundos de contextos periféricos do capitalismo, compostos por latino-americanos, asiáticos, africanos, incluindo refugiados políticos de diferentes nacionalidades, e em diversas circunstâncias.

Esse novo perfil do imigrante do início do século XXI merece ser investigado, porque representa a síntese de situações histórico-estruturais, ao passo que evidencia as condições da atual sociabilidade capitalista. Dentro dessa conjuntura, estabeleceu-se como recorte empírico para investigação o movimento internacional de trabalhadores haitianos, oriundos da periferia do capitalismo mundial, que em circunstâncias de clandestinidade, aliciados por redes de tráfico de pessoas, aportam na região da Amazônia Sul-Ocidental, e posteriormente são recrutados para integrar a linha de produção das empresas capitalistas do CentroSul do país.

Como parte integrante da "classe-que-vive-do-trabalho" (ANTUNES, 2009), esse imigrante pobre e negro, caracterizado, em sua maioria, por ser homem, em idade ativa, de origem rural, com reduzida ou nenhuma escolaridade, é impelido a fugir da sua terra natal sozinho ou em grupo, e tem sido direcionado ao Brasil, país no qual deposita sonhos e esperança de reconstrução de uma vida socialmente digna por meio do trabalho. Um conjunto de fatores estruturais atua 
como propulsor dessa saída dos haitianos da sua terra natal, processo histórico mais conhecido como "diáspora haitiana", que se configurou no compasso de uma longa história de regimes escravocratas, ditaduras militares e intervenções internacionais, conduzidos por colonizadores e imperialistas, acentuados, em alguns momentos históricos, por tragédias socioambientais.

Esses processos instauraram caos político, espoliação, extorsão, violência e um profundo abismo entre o Estado e a população local (HALLWARD, 2006), cuja consequência direta tem sido a fuga e a dispersão de nacionais haitianos pelo mundo. Atualmente, a comunidade haitiana vivendo fora do país é estimada entre 2 e 3 milhões (HAITIAN DIASPORA, 2011; TÉLÉMAQUE, 2012), entre eles profissionais de diversas áreas, escritores, artistas e intelectuais, mas também milhares de trabalhadores precarizados, o que tem levado a um esvaziamento considerável de seu capital humano e profissional (MAMED, 2014).

Desde 2004, o Haiti vem sendo conduzido oficialmente por instituições internacionais lideradas pela Organização das Nações Unidas (ONU). No plano econômico, o Banco Interamericano de Desenvolvimento (BIRD) definiu as estratégias de curto e médio prazo, investindo milhões de dólares em projetos de zonas francas. Essa incisiva atuação das forças internacionais no Haiti foi fortalecida pela concepção e atuação da Missão das Nações Unidas para a Estabilização no Haiti (Minustah), que corresponde à oitava missão da ONU no país, definida para atuar por seis meses, a partir de junho de 2004, mas que vem sendo continuadamente ampliada, estando hoje no seu décimo ano, sob a liderança do Exército Brasileiro (CARREIRO, 2009).

Desse modo, no curso das reformas econômicas neoliberais implementadas em grande parte dos países da periferia capitalista, que restauraram padrões coloniais de exploração, a Minustah viabiliza as condições necessárias para que a política imperialista continue a ser aplicada no Haiti (HARVEY, 2004; SEGUY, 2010). Ao contrário da ajuda humanitária e da missão de paz que divulgam promover, discurso que foi reforçado após o terremoto ocorrido no país em 12 de janeiro de 2010, as tropas militares têm provido serviços de segurança para possibilitar condições de atuação privada e de cooperação governamental, isto é, assegurando a implantação do projeto neoliberal debaixo de armas.

Ao impedir a organização social e sindical, a presença militar no Haiti protege os interesses das empresas internacionais hoje atuantes no país, dentre as quais estão as brasileiras do setor têxtil, construção civil e agroindústria (CHOSSUDVSKY, 2013). Com a promessa de reconstrução econômica e social com geração de empregos, conduzem uma política para transformar o Haiti em um território composto por zonas francas controladas por maquiladoras, 
especialmente norte-americanas, que pagam, proporcionalmente, o menor salário do mundo (GLASS, 2004; SEGUY, 2014).

Atualmente, a economia haitiana concentra-se nas áreas alimentícia (grãos e carne), têxtil, siderúrgica (ferro e aço) e petroquímica (plástico e borracha). O contexto rural do Haiti ainda concentra a maior parte da população total, formada, em sua maioria, por pequenos produtores familiares vivendo em condições sociais de profunda carência. Ainda que não possuam titulação para uso, eles têm acesso à própria terra. Em contrapartida, as políticas induzidas historicamente pelos Estados Unidos e organismos financeiros internacionais impuseram a redução do tamanho médio das propriedades para menos de um hectare, a queda dos preços agrícolas, a drástica erosão do solo e a falta crônica de investimentos, fazendo com que a maior parte desses pequenos produtores rurais mantenha a sua independência à custa de privações permanentes.

$\mathrm{Na}$ década de 1990, como parte da receita do Fundo Monetário Internacional (FMI) para o tratamento da pobreza no país, foi aplicada a reorientação da produção doméstica para os produtos agrícolas comerciais direcionados aos supermercados norte-americanos, a eliminação das tarifas de importação e um ajuste drástico dos salários locais. Como consequência dessa e de outras reformas econômicas correlatas, a capacidade produtiva do país, que em 1970 chegou a produzir 90\% da sua demanda alimentar (SADER et al., 2006), foi sendo destruída. A produção agrícola caiu de cerca de $50 \%$ do Produto Interno Bruto (PIB) no final da década de 1970, para apenas 25\% no final dos anos 1990. Os organismos internacionais alegavam que o ajuste estrutural compensaria o colapso agrário com a expansão dos setores de indústria leve e de montagem (HALLWARD, 2006; VILLELA, 2012). Mas não foi isso o que efetivamente aconteceu, pois no começo da década de 1980, as empresas estrangeiras estabelecidas no Haiti, carentes de força de trabalho, foram as mais beneficiadas por essas intervenções, que liberaram trabalhadores para as zonas francas e parques industriais (SEGUY, 2014).

Os salários mais baixos do hemisfério, sustentados pela quase proibição de sindicatos, encorajaram empresas e empreiteiros internacionais a empregar cerca de 60 mil pessoas nesse setor até meados da década de 1990. Em 1999, os poucos haitianos que trabalhavam no pequeno setor industrial e de montagem do país, considerados privilegiados, ganhavam salários estimados em menos de 20\% do nível de 1981. Mesmo assim, taxas de exploração ainda mais vantajosas estimularam muitas dessas companhias a mudar a sua base produtiva para a China e Bangladesh, e somente umas 20 mil pessoas permaneceram empregadas nas fábricas de Porto Príncipe, na virada do século XX (HALLWARD, 2006). 
Em 1950, a população do Haiti era de 3,2 milhões de habitantes, e a distribuição espacial da população indicava um país com forte composição rural, com $87 \%$ residindo nas áreas rurais. Contudo, com a degradação das terras rurais houve grande êxodo rural-urbano e no ano 2000 a população já era de 8,5 milhões, com redução para 65\% o percentual dos habitantes da área rural. No plano econômico, apesar de um pequeno aumento do PIB em 2007, da ordem de $3,4 \%$, a maioria da população vivia em condição de pobreza extrema, com estimativas indicando o percentual de $56 \%$ do total com renda inferior a US $\$ 1,00$ (um dólar) por dia e 76\% com renda inferior a US\$2,00 (dois dólares) diários. Em 2009, 53,1\% da população ainda vivia no campo, mas segundo o Censo de 2003, o Departamento Oeste do país, onde se localiza a região metropolitana de Porto Príncipe, já concentrava $23 \%$ da população total, e apresentava uma taxa de urbanização da ordem de 55\% (ROUSSEAU, 2010).

Em 2010, a população chegou a cerca de 10 milhões, com aproximadamente $50 \%$ residente no campo e 50\% concentrada no ambiente urbano. A redução da produção agrícola e o quadro crescente de pobreza acelerou a dilatação urbana; no entanto, as cidades não oferecem alternativas de emprego, pois a prometida expansão industrial não tem sido capaz de absorver a força de trabalho local em constante crescimento. Antes do terremoto de 2010, o país já importava cerca de $55 \%$ de todos os gêneros alimentícios consumidos; e após a tragédia, a importação desses gêneros saltou para 80\%. Por outro lado, os residentes no interior passaram a sofrer com a pressão dos empreendimentos multinacionais agropecuários, de mineração e de turismo de luxo, que, ao se estabelecerem, demandam a expulsão da população do campo, ampliando a concentração populacional nas maiores cidades do país (COGGIOLA, 2010).

No quadro urbano do Haiti, após o sismo, o pequeno parque industrial da capital do país, Porto Príncipe, logo foi recuperado e reaberto, mas sob uma nova articulação. Desde então, a sua principal produção são produtos têxteis exportados aos Estados Unidos, visto que o Haiti apresenta hoje custos trabalhistas inferiores aos da China, referência mundial no assunto, e a força de trabalho haitiana não é apenas barata, mas qualificada, com tradição em tecelagem. Ademais, foi definitivamente regulamentado o intercâmbio comercial com os EUA, com a assinatura da Lei de Oportunidade para o Haiti no Hemisfério por meio do Estímulo a Parcerias (Lei Hope), promulgada no ano de 2006, que revogou barreiras comerciais e anistiou pagamentos de taxas alfandegárias, de maneira que os produtos norte-americanos e haitianos passaram a ter trânsito livre no território dos dois países (COGGIOLA, 2010; HALLWARD, 2006). 
Os poucos haitianos que conseguem emprego formal são submetidos a longas jornadas de trabalho nas fábricas, em sua maioria terceirizadas nas zonas francas, e em condições laborais deploráveis. Isso assegura a produção de mercadorias a custos mínimos para o capital, em uma região estratégica, localizada na costa dos Estados Unidos (ALMEIDA, 2010). O salário mínimo no Haiti no momento de redação deste texto (2014) era de 225,00 goudes por dia, o equivalente a 110,00 dólares ao mês. A título de comparação, o salário mínimo na China equivalia a 248,00 dólares, e no Brasil a 327,00 dólares. Desse modo, as multinacionais podem produzir no Haiti pagando duas vezes menos aos trabalhadores que na China, a uma distância da costa dos EUA doze vezes menor; ou pagar três vezes menos que aos trabalhadores brasileiros, a uma distância quase seis vezes menor da costa americana (ALMEIDA, 2010; COGGIOLA, 2010).

As fábricas têxteis, por exemplo, têm pequena exigência de capacitação tecnológica, o que torna desnecessário investir em educação e formação técnica. Por conseguinte, as empresas operam tendo à sua disposição um exército industrial de reserva estimado em $80 \%$ de desempregados, e não pagam nenhuma das conquistas trabalhistas dos séculos XIX e XX, como férias, décimo terceiro e aposentadoria. Também não pagam praticamente nenhum imposto ao Estado, que, por sua vez, não assegura saúde nem educação ao cidadão (ALMEIDA, 2010).

Em um país com alto desemprego ou subemprego desempregada, a promessa de trabalho assume importância fundamental, porém, sem a contrapartida da reconstrução social, educacional e habitacional. Esse fato revela que a ajuda humanitária internacional foi moldada para renovar os empreendimentos capitalistas internacionais, além de ensejo para o enraizamento da intervenção militar imperialista no Haiti (COGGIOLA, 2010; SEGUY, 2014). A maior demonstração disso é que $76,7 \%$ do valor dos contratos concedidos pela União Europeia em seus projetos de reconstrução no país foram entregues a companhias europeias, já os Estados Unidos cederam somente 1,3\% do valor contratual de seus projetos a empresas haitianas (FRESNILLO, 2014).

Ao todo, dos cerca de 10 bilhões de dólares prometidos ao Haiti em janeiro de 2010, menos de 5\% passaram pelas mãos das instituições estatais ou das organizações da sociedade civil haitiana. Estimativas indicam que metade desses recursos tenha ficado com organismos internacionais e tenha sido gasto com ajuda humanitária, postos de trabalho de curto prazo, abrigos e remoção de escombros (GOMBATA, 2014). Quatro anos após o terremoto que deixou 240 mil mortos, aproximadamente 1,5 milhão de desabrigados e reduziu a 
escombros uma parcela importante da infraestrutura habitacional e governamental do Haiti, não se constata a reconstrução do país e da vida daqueles que perderam tudo ou quase tudo o que tinham. $\mathrm{Na}$ verdade, a situação social da nação mais empobrecida do continente americano permanece preocupante (GOMBATA, 2014; FERNANDES; MILESI; FARIAS, 2014).

De colônia mais rica a país mais pobre das Américas, o Haiti possui, portanto, uma história que incidiu na precarização de sua sociedade, processo que estruturou as condições para a sua diáspora. A numerosa população e o imenso exército de reserva que esta significa, assegura a força de trabalho e a imposição social sobre os poucos que trabalham, para que não se mobilizem por melhorias. Pressionados pela condição social de pobreza, carência e falta de trabalho que assegure o seu estabelecimento no campo ou na cidade, os haitianos oscilam entre esses dois universos, tentando resguardar a sua reprodução social em múltiplas atividades informais.

Decorridos dez anos de ações da Minustah e quatro anos de ajuda humanitária no pós-terremoto, $80 \%$ da população segue vivendo abaixo da linha da pobreza e mais de 170 mil pessoas ainda moram em tendas dispostas em acampamentos a céu aberto (FRESNILLO, 2014). O Haiti enfrenta, assim, um processo particular de colonização e imperialismo, que evidencia as faces mais perversas do modo de produção capitalista, exacerbado pela agenda neoliberal: o desemprego atinge de 70 a $80 \%$ da população; mais de $70 \%$ da população ainda vive com menos de 2,0 dólares por dia; o índice analfabetismo alcança 50 a $60 \%$ em todo o país; a crônica ausência de água e esgoto nas casas favorece a constante disseminação de doenças e epidemias; o limitado sistema elétrico abastece poucas moradias, e é frequentemente cortado sem aviso prévio; os moradores das cidades andam longos percursos porque não dispõem de recursos para custear um meio de transporte; e a maior parte dos habitantes não existe oficialmente, pois não possui documentação (ALMEIDA, 2010; BRITO, 2009; COGGIOLA, 2010).

Portanto, a confluência de um processo de formação social, política e econômica bastante peculiar com a ocorrência de desastres socioambientais, a partir de 2010, reforçou os fatores de expulsão do país, que contribuem para a gestação e ampliação de uma diáspora (JACKSON, 2013). Assim, expressiva parcela da população haitiana tem sido impulsionada ou mesmo forçada a deixar o seu país em busca de melhores condições de vida. O Brasil, ainda que não fosse o destino prioritário, provavelmente é o país mais procurado pelos imigrantes haitianos atualmente, cuja presença no território brasileiro vem se ampliando rapidamente desde 2010 . 
De acordo com a Polícia Federal brasileira, 39 mil haitianos entraram no país de 2010 até setembro de 2014, tanto pela via considerada legal quanto pela ilegal (ACNUR, 2014). Segundo o governo do estado do Acre, que é a principal porta de entrada desses imigrantes no país, somente pela fronteira acreana passaram mais de 28 mil até dezembro de 2014 (MACHADO, 2014d); e os prognósticos indicavam que eles seriam em torno de 50 mil até o final de 2014 (FERNANDES, 2014). A despeito da imprecisão, os números são importantes indicadores de que o país ocupa definitivamente uma posição central nesse fluxo migratório, sobretudo pela maneira como os deslocamentos de caribenhos e africanos são realizados até o Brasil, estruturados, como indicado anteriormente, a partir da atuação de redes de tráfico de pessoas e coiotagem.

\section{IMIGRANTES HAITIANOS EM MOVIMENTO PELO MUNDO DO TRABALHO: A SAÍDA DO HAITI E A CHEGADA AO BRASIL PELA FRONTEIRA DO ACRE}

Historicamente, os trabalhadores haitianos são compelidos a abrir trilhas em busca de trabalho, configurando movimentos migratórios desenhados em várias direções e em fases distintas. $\mathrm{O}$ registro do primeiro deslocamento internacional ocorreu em direção a Cuba, no final do século XIX. No entanto, com a crise que afetou a indústria do açúcar nos anos 1930, eles foram expulsos da ilha Charuto, onde ainda existe uma comunidade haitiana com cerca de 80 mil pessoas (TÉLÉMAQUE, 2012). Expressivo movimento também se deu na década de 1960, em direção a Miami, Bahamas, Martinica, Guadalupe, Guiana Francesa, entre outros, que careciam de força de trabalho para estruturação de suas atividades econômicas, ao mesmo tempo em que o Haiti vivia um de seus momentos políticos e econômicos mais críticos (HUNTINGTON, 1997; TÉLÉMAQUE, 2012).

As rotas desse movimento se expandiram, podendo ser encontrados haitianos na América, Europa, Ásia, África e Oriente Médio. Historicamente, os principais países que os receberam foram Estados Unidos (mais de 1 milhão), República Dominicana (500 mil), Cuba (300 mil), Canadá (150 mil), França (100 mil) e países da América do Sul (75 mil) (TÉLÉMAQUE, 2012). Entre as décadas de 1960 e 1980, a fuga dos haitianos combinou incentivos financeiros à perseguição ou ameaças de natureza política, correspondendo a uma migração pelo sistema convencional e legal. Esse movimento de refugiados políticos era composto majoritariamente por membros das classes superiores urbanas, 
intelectuais, profissionais diplomados, artistas e estudantes que se opunham à ditadura estabelecida no país.

Outra onda, desta vez mais expressamente econômica, iniciou nos anos 1990, e desde então, haitianos em busca de trabalho cruzam a fronteira por terra, em direção à República Dominicana, ao passo que outros deixaram o país em embarcações frágeis e perigosas, com destino aos Estados Unidos e, mais recentemente, muitos recorrem às viagens organizadas por redes de coiotagem e tráfico de pessoas para acessar territórios mais distantes. O fluxo de haitianos para o Brasil iniciou-se de modo tímido, em dezembro de 2010, ou seja, ao final do mesmo ano em que ocorreu o cismo, mas vem se intensificando desde o final de 2011 e começo de 2012. O anseio de escapar das restrições econômicas e sociais imperativas do Haiti, intensificadas após o terremoto, conjuga-se com uma nova fase da política imigratória do Brasil, aberta para o recebimento de estrangeiros.

Contrariando muitas abordagens superficiais sobre a questão, a motivação para esse deslocamento não se justifica pela ocorrência do terremoto, mas por uma combinação de fatores específicos do contexto haitiano, no qual a reestruturação produtiva, a mundialização da economia, as políticas neoliberais, a precarização e a desigualdade potencializaram os desdobramentos dos impactos do terremoto, fortemente marcados por epidemias, desemprego, miséria e fome. A síntese dessas circunstâncias concorreu para o estabelecimento de um forte movimento internacional de trabalhadores haitianos em direção ao Brasil. Compelidos pela crise em seu país de origem, e diante das atuais dificuldades para acessar os países do capitalismo central na América do Norte e na Europa, esses imigrantes têm feito do Brasil a referência para a sua acolhida (MAMED; LIMA, 2014, 2013a, 2013b).

A maioria é atraída pela posição do país como mercado econômico emergente, o que fomenta expectativas de conquista de trabalho, emprego, saúde, educação, estudo e estabilidade. As parcerias que o governo, organizações não governamentais (ONGs) e empresas brasileiras vêm firmando no Haiti, em projetos de desenvolvimento, sobretudo desde 2004, concorrem fundamentalmente para esse direcionamento. O Brasil tornou-se atrativo para os haitianos justamente a partir da liderança da Minustah, reforçada pela presença de ONGs e profissionais brasileiros que atuam de modo contundente na ilha, compartilhando com a população local referências e símbolos socioculturais (MORAES; ANDRADE; MATTOS, 2013).

Como membro do processo de reconstrução do país, o Brasil também mantém diversos projetos em seu território, com destaque para o auxílio na 
construção da usina hidrelétrica no rio Artibonite, no sul do país, financiada pelo Banco Nacional de Desenvolvimento Econômico e Social (BNDES), com licitação restrita a empreiteiras brasileiras. No segmento têxtil, um dos mais tradicionais do Haiti, a Companhia de Tecidos Norte de Minas (Coteminas), da família do vice-presidente brasileiro entre os anos de 2003 e 2010, também opera na ilha, beneficiando-se das vantagens proporcionadas às zonas francas industriais. Por sua vez, a Empresa Brasileira de Pesquisa Agropecuária (Embrapa) também desenvolve importantes projetos experimentais naquele país.

A região da Amazônia Sul-Ocidental (estado do Acre) é a principal porta de entrada de haitianos no país. Até 2013, eles também utilizavam uma rota configurada pela cidade de Tabatinga, no estado do Amazonas, região da fronteira entre Brasil, Peru e Colômbia. Porém, ao chegarem nesta cidade, não contavam com nenhuma estrutura de apoio local e precisavam seguir de barco para a capital, Manaus, em uma viagem de quase cinco dias pela Bacia Amazônica. Aos poucos, as dificuldades encontradas foram tornando o fluxo por esse caminho inconstante, até torná-lo praticamente inviabilizado. Assim, a principal rota de acesso ao Brasil se dá pela Rodovia Interoceânica ${ }^{2}$ até o Acre, envolvendo uma série de redes ilegais de tráfico de pessoas, coiotes e informantes.

Pela viagem do Haiti ao Brasil, os imigrantes pagam, em média, de US $\$ 2$ mil a US $\$ 5$ mil pela viagem em grupos, e são vítimas frequentes de diversos tipos de extorsões, roubos, cárceres, espancamentos, estupros e até mortes situação agravada pelo desconhecimento do idioma local e, especialmente, pela condição de indocumentados (FERRAZ, 2014; MACHADO, 2012; MAMED; LIMA, 2014, 2013a, 2013b). Muitos chegam ao Acre com problemas de saúde decorrentes da longa viagem, e psicologicamente transtornados pela violência que sofreram no caminho. Entretanto, ante ao temor de sofrerem retaliação, preferem silenciar sobre os detalhes da viagem e o funcionamento das redes (MACHADO, 2012).

Há inúmeros relatos e denúncias de que a polícia peruana, agentes e taxistas peruanos, bolivianos e brasileiros, além de informantes haitianos componham essas redes e exerçam a prática da extorsão contra os grupos de imigrantes. Instituições e pesquisadores que acompanham, no Acre, o trânsito deles pela região, estimam o custo aproximado de $\mathrm{R} \$ 6$ bilhões em pagamentos às redes de

\footnotetext{
Inaugurada em julho de 2011, a rodovia é fruto de um dos mais ambiciosos projetos da Iniciativa para a Integração da Infraestrutura Regional Sul-Americana (IIRSA), financiado por organismos mundiais. Seu propósito é flexibilizar as fronteiras para a integração econômica internacional, assegurando resultados máximos ao livre mercado, especialmente de commodities. Sobre os interesses do capital, viabilizados pela IIRSA na Amazônia, consultar Cunha e Cunha (2008); e para conhecimento da importância infraestrutural da rodovia Interoceânica como corredor de exportações e da mercadoria força de trabalho, consultar Paula (2013).
} 
tráfico e corrupção estruturadas com esse movimento migratório (ARRUDA, 2014). Para assegurar o negócio, as organizações criminosas que lucram com a passagem e o transporte desses imigrantes reforçam a ideia do Brasil como país da esperança e da oportunidade, motivando-os a emigrar. É o que explica um dos funcionários públicos que recebem e acompanham diariamente os imigrantes em território acreano:

Os coiotes de lá iludem os haitianos com a história de que, no Brasil, podem ganhar salários de 2 mil dólares. Pelos relatos que ouvi das pessoas que chegaram a Brasiléia do ano passado para cá, 95\% dos imigrantes passam obrigatoriamente pelo Equador. $\mathrm{Na}$ fronteira do Equador com o Peru, os haitianos chegam a pagar 250 dólares por um carimbo falso de entrada no país (BORGES, entrevista, 2013).

De acordo com o relato da maioria dos entrevistados, e conforme as informações que o Sistema de Justiça do Brasil detém sobre essa questão, os imigrantes haitianos que chegam ao país na condição de indocumentados, em sua maioria, partem da capital haitiana, Porto Príncipe, e vão de ônibus até Santo Domingo, capital da República Dominicana, que fica na mesma ilha. Nesta cidade, compram passagem de avião ou barco e seguem até o Panamá. Da Cidade do Panamá eles prosseguem de avião ou de ônibus para Quito, no Equador, onde não é necessário visto para entrada e permanência no país. Em Quito eles se reorganizam e seguem a viagem em veículo fretado ou mesmo a pé, acompanhados por coiotes. O percurso se dá pelas arriscadas estradas latinoamericanas, passando pela cidade fronteiriça peruana de Tumbes, depois por Piura, até chegarem a Lima, onde acessam a Rodovia Interoceânica, que conecta o Peru ao Brasil pela fronteira do Acre.

Eles partem de Lima, passam por Cusco e Puerto Maldonado, onde alugam um carro até Ibéria. Neste ponto, os coiotes os levam até Iñapari, última cidade peruana antes de ingressarem no território brasileiro. Ao atravessar a fronteira do Peru com o Brasil, eles passam pela cidade de Assis Brasil até chegar às cidades gêmeas de Epitaciolândia e Brasileia, onde se localiza a Delegacia de Polícia Federal responsável pela região fronteiriça, e onde estava sediado, até abril de 2014, o acampamento para acolhida dos imigrantes.

Desde então, eles se dirigem ao novo endereço do abrigo, localizado na capital do Acre, Rio Branco. A viagem tem duração média de 15 dias, podendo se estender até mais de um mês, em alguns casos (MAMED; LIMA, 2014). O relato a seguir indica as circunstâncias da viagem, a visão do haitiano sobre o país e as perspectivas sobre uma nova vida no Brasil: 
Lá no Haiti há muita crise e miséria, por isso temos que sair, por necessidade, então se vende a terra, se vende a vaca, se vende tudo o que tem para vir pra cá, porque não pode chegar aqui sem uma coisa, para que se viaje bem, porque os peruanos nos dão um visto por 200 dólares para que a gente possa entrar aqui sem problemas. [...] Cheguei ao Brasil e gostaria muito de reencontrar minha felicidade aqui. Todos, o governo, a polícia, todos nos tratam muito bem [...], por isso nós queremos viver aqui, trabalhando com tranquilidade. Nós temos o Brasil como um braço do nosso país, uma porta aberta para todos os haitianos [...] (VILBRUN, entrevista, 2013).

Homens, mulheres e crianças chegam diariamente pela Interoceânica, em média, de 30 a 50 imigrantes, de acordo com a Secretaria de Desenvolvimento Social (SEDS) e a Secretaria de Justiça e Direitos Humanos (SEJUDH), responsáveis pelo atendimento aos estrangeiros que ingressam pelo Acre. Os primeiros registros de haitianos nas cidades acreanas de fronteira (Assis Brasil, Brasiléia e Epitaciolândia) são de dezembro de 2010, com a chegada de pouco mais de 30 imigrantes, todos homens e jovens, antes mesmo da rodovia ter sido oficialmente aberta. Nos anos de 2011 e 2012, os números foram de 1.175 e 2.225 imigrantes, respectivamente. Esse número foi exacerbado no ano de 2013, quando 10.779 haitianos chegaram à região. A tendência de crescimento continua, e estima-se a passagem de mais de 31 mil imigrantes pela fronteira acreana até dezembro de 2014, principalmente haitianos, mas também de outras nacionalidades (SEDS, 2014; SEJUDH, 2013, 2014).

Nos últimos dois anos é notável o crescimento do número de mulheres, crianças e idosos compondo os grupos que chegam ao Acre. A maioria, porém, ainda é representada por homens jovens, de 20 a 40 anos, mas com a presença de um percentual significativo de imigrantes acima de 40 anos e de menores de 18 anos. De modo geral, o perfil do imigrante recebido e abrigado é configurado da seguinte forma: $80 \%$ de homens, $15 \%$ de mulheres e $5 \%$ de crianças. Até abril de 2012, os imigrantes que chegavam ao Brasil através da rota consolidada pelo Acre eram exclusivamente haitianos, em grupos formados por homens jovens. Desde então houve o crescimento do número de idosos, mulheres (com filhos, gestantes e desacompanhadas), crianças, famílias e até pessoas doentes.

As mulheres acompanhadas de crianças buscam, em sua maioria, chegar às cidades onde os seus pais e companheiros já estão trabalhando no Brasil. Por sua vez, os homens chegam ao Brasil graças a um investimento feito por toda a família, que elegem um membro para tentar trabalhar e estudar no Brasil, e posteriormente ser capaz de receber os outros parentes. Em geral, a família procura algum tipo de financiamento para custear a viagem organizada 
por coiotes, como a hipoteca de bens que a família possui, fazendo com que o imigrante haitiano chegue ao Brasil com a necessidade imperiosa de trabalhar para quitar o endividamento contraído e enviar recursos para a sobrevivência dos seus familiares que permaneceram na terra natal. Em razão desse aspecto, o próprio Estado haitiano de alguma forma, incentiva a saída, visando o importante fluxo econômico com as remessas ${ }^{3}$ de recursos financeiros por imigrantes a seus parentes no Haiti (MAMED; LIMA; 2013a, 2013b).

A consolidação dessa rota de entrada no Brasil tem favorecido a chegada de pessoas de outros países ao acampamento público montado no Acre. Em torno de 17 diferentes nacionalidades já passaram pelo local, mas todos os imigrantes igualmente vítimas do aliciamento de coiotes. O novo perfil é representado especialmente por aqueles advindos do continente africano. Nos anos de 2013 e 2014, por exemplo, houve um considerável crescimento no número de imigrantes senegaleses, o que faz deste o segundo maior grupo de estrangeiros presentes no Acre. A rota percorrida por estes segue, em geral, um percurso que inicia em Dakar, capital senegalesa, na viagem de avião com uma escala em Madri, na Espanha, e de lá prossegue para o Equador. Ao chegarem em Quito, eles passam então a seguir a mesma rota dos haitianos, passando pelo Peru via Rodovia Interoceânica até o Acre. Os senegaleses justificam suas motivações para a vinda ao Brasil em razão das oportunidades de trabalho abertas pela Copa do Mundo e Olimpíadas, do conhecimento da rota e da história que os haitianos vêm construindo no país, assim como pelas experiências de compatriotas que já se estabeleceram nas cidades brasileiras (BÄCHTOLD, 2013; MACHADO, 2014b).

No cotidiano do acampamento instalado no Acre, o encontro e a convivência entre imigrantes de diversas nacionalidades nem sempre é cordial e solidário. Há, por exemplo, uma grande disputa entre haitianos e senegaleses por atenção, território e comida, o que gera brigas ocasionais entre os grupos.

\footnotetext{
As remessas de migrantes correspondem à fração dos salários desses trabalhadores, que não é utilizada por eles, sendo então enviada aos parentes que ficaram no seu país de origem. Assim, é possível postular a existência de uma proporcionalidade direta entre o volume do fluxo migratório e o valor total das remessas de dinheiro, de modo que, quanto maior for o contingente migratório, maiores serão essas remessas. No caso do Haiti, as remessas dos imigrantes, especialmente dos residentes em países de capitalismo central, superam as exportações haitianas, sendo o oitavo país mais dependente de remessas externas do mundo, algo que representa entre 20 e $25 \%$ do seu PIB. Mais de um terço da população adulta do Haiti recebe pagamentos regulares de remessas, sendo a maior parte proveniente dos Estados Unidos. Com a intensificação da imigração haitiana após o sismo de 2010, os dados do Banco Interamericano de Desenvolvimento (BID) indicam que o volume dessas remessas apresenta um crescimento: em 2010 era de apenas US $\$ 1,3$ bilhão; em 2011, foi de quase US $\$ 2,1$ bilhões; em 2012, alcançou US\$ 1,82 bilhões (CEPAL, 2006; MALDONADO; BAJUK; HAYEM, 2012; SÔNEGO, 2012).
} 
Com diferenças econômicas, culturais e religiosas bem demarcadas, o contato entre essas nacionalidades tem exigido atenção especial da administração do acampamento, que em alguns momentos requisita reforço policial para garantir a segurança do local. Esses desentendimentos e conflitos tendem a aumentar, principalmente nos momentos de superlotação, quando o temor da falta de água, comida, espaço e a própria concorrência pelas vagas de trabalho afligem os imigrantes e os colocam em disputa entre si no interior do abrigo.

O "sonho brasileiro", fruto da necessidade premente de recomeçar a vida, e assim poder ajudar a família, tende fazer desses trabalhadores um "alvo fácil do arbítrio de organizações criminosas", como as que operam o tráfico de pessoas referente ao transporte de força de trabalho, e posteriormente dos próprios empregadores no lugar de destino (VILLEN, 2012, p. 6). A pesquisa tem confirmado que a aspiração de fugir dos problemas de falta de trabalho, educação, saúde, habitação e segurança no seu país de origem vem impulsionando a migração rumo ao Brasil, seja pela via considerada legal ou ilegal. Com isso, a questão tornou-se um nicho de negócios no Haiti, onde despachantes, falsificadores, aliciadores, coiotes, atravessadores e negociadores em geral tentam lucrar com o processo de agenciamento (STOCHERO, 2013). Relatos informam que existe naquele país a venda de vistos e outros documentos falsificados, inclusive supostas facilidades que prometem acelerar a viagem. Do mesmo modo, há denúncias de que agentes públicos do Estado haitiano atuam na organização de grupos e na preparação da viagem para o Brasil.

A partir do material coletado em campo, e com base na recente avaliação do Governo Federal sobre o perfil do estrangeiro que ingressa no país pelo $\mathrm{Acre}^{4}$, considera-se que no primeiro ano deste fluxo eles provinham, na maioria dos casos, das áreas urbanas e mediações da cidade de Porto Príncipe, epicentro do terremoto de 2010. No entanto, nos últimos três anos, o perfil do imigrante haitiano vem se alterando, sendo atualmente a maioria de origem rural, das regiões e cidades não afetadas pelo sismo. Ainda com base nas mesmas fontes de pesquisa, é importante observar as mudanças com relação ao aspecto da escolaridade desses estrangeiros. No primeiro ano de fluxo migratório pela fronteira acreana, muitos declaravam possuir experiência profissional e formação equivalente ao

4 Trata-se de uma aferição empírica promovida pela Secretaria de Direitos Humanos da Presidência da República (SDH/PR) sobre a situação dos migrantes e/ou solicitantes de refúgio no Acre (SDH/PR, 2014). As informações coletadas por meio dessa ação estão reunidas no documento "Resultado da Aplicação do Questionário sobre a Situação dos/as Migrantes e/ou Solicitantes de Refúgio no Abrigo de Brasiléia/AC - Para Uso Interno do Serviço Público Federal", que foi disponibilizado ao público pela SDH/PR em março de 2014. A ação envolveu a aplicação de 412 questionários no período de 30.10.2013 e 02.11.2013, no acampamento público de imigrantes existente, à época, na cidade de Brasiléia/AC. 
nível superior e à pós-graduação no Brasil. Entretanto, nos últimos dois anos, tem sobressaído entre os imigrantes a reduzida escolaridade, equivalente ao Ensino Fundamental e ao Ensino Médio do país, incluindo casos de analfabetismo. Do ponto de vista da experiência e das habilidades profissionais, a maioria informa conhecer as atividades agrícolas e já ter atuado na construção civil e no comércio informal.

Ao chegarem ao Acre, debilitados, após semanas de viagem, sem perspectiva de ocupação na região Sul-Ocidental da Amazônia, e sem dinheiro para prosseguir viagem até os grandes centros do país, os imigrantes são acolhidos por um complexo de serviços do Estado brasileiro, estruturado em parceria pelos governos federal e estadual. O núcleo desse complexo é o local que serve de acampamento aos imigrantes, e já passou por vários endereços nas cidades gêmeas de Brasiléia e Epitaciolândia (a 230 km de Rio Branco, capital do Acre), pela necessidade de ampliar o espaço de acolhimento, em razão da demanda de estrangeiros recebidos. Em abril de 2014, o acampamento foi transferido dessa região de fronteira para a capital acreana, e atualmente está em seu oitavo endereço - o segundo somente em Rio Branco.

O lugar onde o acampamento permaneceu por mais tempo, entre fevereiro de 2013 e abril de 2014, no centro da cidade de Brasiléia funcionou em condições improvisadas e insalubres, reveladoras da condição de precarização a que vinham sendo submetidos os estrangeiros que adentravam o Brasil pela fronteira amazônica. Este espaço foi alvo da atenção primordial das visitas de campo da pesquisa durante os anos de 2013 e 2014. Neste local, a situação dos imigrantes do século XXI remontava à condição dos imigrantes irlandeses e escoceses na composição da classe proletária na Inglaterra do século XIX (ENGELS, 2008). A permanência diária no local girava em torno de 500 e 1.000 pessoas, sendo que a sua capacidade era para apenas 200 ou, no máximo, 300. Já no atual acampamento, dotado de ampla infraestrutura para o acolhimento dos imigrantes, há um esforço institucional para que o número de abrigados não ultrapasse o limite de 200 pessoas, meta que se busca atingir com a organização de viagens de grupos que saem diariamente do abrigo de Rio Branco, em ônibus fretados, com destino às cidades do Centro-Sul, como São Paulo e Porto Alegre. Contudo, em dezembro de 2014, a tendência de superlotação do acampamento voltou a ser uma constante.

Desde o início, a política de atendimento ao imigrante desenvolvida no Acre introduziu, na própria sede do acampamento, uma estrutura mínima de serviço público brasileiro, que tanto presta informações e orientações ao imigrante como organiza e monitora o espaço. Quando adentram a fronteira brasileira, os imigrantes 
já se encaminham para este acampamento, onde são recebidos e cadastrados pela coordenação do local, por meio de uma ficha de identificação para coleta dados sobre seus documentos, procedência, saúde, escolaridade, profissão, destino no Brasil, entre outras informações. Depois disso, eles recebem as instruções sobre o procedimento de legalização da sua situação e a retirada da documentação mínima necessária para transitar e trabalhar no Brasil, como a solicitação de refúgio na Polícia Federal; o Cadastro de Pessoa Física (CPF), na Receita Federal; e a Carteira de Trabalho, no Ministério do Trabalho e Emprego (MTE).

A documentação fica pronta em um prazo de 5 a 15 dias, tornando-os aptos a trabalhar e seguir viagem. Com a documentação em mãos, a maior parte dos imigrantes permanece no abrigo aguardando o dia da viagem nos ônibus fretados pelo governo, ou a chegada de empresas que os recrutam para levá-los aos estados do Centro-Sul do Brasil. Eventualmente, quando eles conseguem receber algum recurso enviado pela família que ficou no Haiti ou por parentes e amigos que já estão trabalhando em alguma parte do mundo, eles próprios organizam a saída do Acre em redes de contatos.

No caso da comunidade haitiana, em particular, a política migratória brasileira atua de modo específico. A Resolução no 97/2012, do Conselho Nacional de Imigração (CNIg), órgão do MTE, definiu os contornos dessa atuação. Conforme a norma, por razão humanitária, considera-se o "agravamento das condições de vida da população haitiana em decorrência do terremoto de 2010" e o visto "tem caráter especial”, sendo válido por cinco anos, podendo ser renovado se o imigrante comprovar a sua condição trabalhista regular no Brasil (MTE; CNIg, 2012). Assim, o país não impede a entrada desses imigrantes, mas nega a condição de refugiado que eles solicitam.

Todos os abrigados no acampamento do Acre são oficialmente solicitantes de refúgio, por orientação do próprio governo brasileiro, que, após seis meses de análise dos pedidos, prorrogados por mais seis meses, nega-lhes a concessão dessa condição. Os haitianos recebem o documento chamado de "visto de permanência provisória por motivos humanitários", que os retêm em uma condição de imobilidade e precariedade. Trata-se de um arranjo legal da política brasileira, que evita a deportação dos imigrantes que chegam ao país, uma vez que a lei proíbe a deportação de solicitantes de refúgio durante o período de tramitação do pedido. O improviso e as contradições dessa política questionam o discurso governamental, que recebe, abriga e documenta, mas não assegura a permanência e proteção definitivas desses trabalhadores.

No plano mais geral, o intenso fluxo de estrangeiros na região revelase associado às mudanças ocorridas nos setores da indústria e de serviços do 
Brasil, acompanhando o seu desenvolvimento, que gera grandes demandas por força de trabalho, especialmente aquela com perfil menos qualificado. O mapa dos empregos no Brasil revela que o aumento no volume de colocações vem ocorrendo, sobretudo, em categorias com baixos salários, no setor administrativo, de comércios e serviços, construção civil e agropecuário, que se caracterizam pela intensa rotatividade da força de trabalho (IBGE, 2013; DIEESE, 2011). Em razão disso, o país é atualmente o segundo maior mercado mundial para o trabalho temporário. Na medida em que a força de trabalho menos escolarizada ou não qualificada continua a ser amplamente utilizada, isso permanece servindo de estímulo ao deslocamento de contingentes populacionais que vivem em regiões onde as possibilidades de trabalho, emprego e sobrevivência são praticamente nulas.

Desse modo, as vias deste circuito e as redes que se estruturam a partir dele podem gerar, em parte, a mediação pela qual ocorre essa grande afluência de imigrantes para o Brasil. Nesse sentido, desde a estruturação do primeiro acampamento público na região de fronteira diversas empresas estabeleceram contato e vêm contratando a força de trabalho imigrante disponível. E quando esse curso de contratações sofre oscilações, por algum motivo, a articulação governamental sempre encontra alternativas para assegurar que a chegada, o acolhimento, a documentação e o encaminhamento deles para o trabalho não sejam interrompidos.

\section{DA AMAZÔNIA PARA O CENTRO-SUL DO BRASIL: TRABALHO, PRECARIZAÇÃO E EXPLORAÇÃO DA FORÇA DE TRABALHO HAITIANA}

Conforme os registros da Sejudh $(2013,2014)$ nesses quase quatro anos do complexo de serviços e acampamento público voltados para o recebimento dos imigrantes, inúmeras empresas estiveram no Acre para recrutá-los, algumas mais de uma vez. As empresas que mais se destacam nesse processo são as do setor agropecuário, especialmente da agroindústria da carne, além da construção civil, metalúrgicas, têxteis, hoteleiras e de serviços de limpeza, todas elas estabelecidas no Centro-Sul do país, principalmente nos estados de São Paulo, Minas Gerais, Paraná, Santa Catarina, Rio Grande do Sul, Goiás e Mato Grosso (SEJUDH, 2013, 2014).

Os frigoríficos brasileiros têm dificuldades para contratar trabalhadores, dadas as circunstâncias precárias de trabalho, com longas jornadas e elevado índice 
de doenças relacionadas a distúrbios mentais, quadros depressivos e tendências suicidas. Por isso, desde 2010 eles têm reforçado a contratação de índios e, mais recentemente, de imigrantes haitianos (PRIMI, 2013). O estado de Santa Catarina é um dos principais destinos de imigrantes recrutados no acampamento da Amazônia acreana, sendo o berço de um dos maiores grupos empresariais do setor, a Brasil Foods (BRF), na cidade de Chapecó, conglomerado do ramo de produtos alimentícios de origem animal, surgida em 2009, a partir da fusão da Sadia com a Perdigão; além de ser a base produtiva do grupo JBS-Friboi, maior processador de carne do mundo.

O período em que o Brasil se tornou o maior produtor mundial de carne foi também quando houve um aumento expressivo dos casos de distúrbios mentais no setor, em razão da intensificação do ritmo de trabalho para cumprir metas diárias de produção. De acordo com os dados do Ministério da Indústria e Comércio do Brasil e do Departamento de Agricultura dos Estados Unidos, entre os anos 2000 e 2010, as receitas com as exportações brasileiras no segmento tiveram um aumento médio de 69,6\% ao ano. Por outro lado, estima-se atualmente que aproximadamente $20 \%$ dos 850 mil trabalhadores do segmento estejam doentes (PRIMI, 2013; REPÓRTER BRASIL, 2013).

O trabalho fragmentado, estruturado na decomposição crescente das tarefas, reduzido a ações mecânicas, repetitivas e intensas, nos moldes do trabalho fundado no taylorismo-fordismo, é a condição marcante na seção de abate e corte desse setor. Apesar de o processo produtivo ter sido alvo de constantes inovações tecnológicas desde 1970, nem todas as etapas da produção industrial de carne puderam ser mecanizadas. Exemplo disso é a atividade de cortes de aves, que continua a apresentar baixa incorporação tecnológica, e boa parte do processo de trabalho é realizado manualmente, em extensas jornadas, com intervalos reduzidos. O trabalhador executa suas atividades em pé, em ambiente insalubre, com baixas temperaturas, muita umidade, odor desagradável e ruído ensurdecedor (NELI; NAVARRO, 2013).

Além disso, é importante destacar que elementos como financeirização da produção e terceirização estão presentes na organização da agroindústria da carne, setor que se conecta com as maiores redes mundiais de fast-food (McDonald's, Burger King etc.) e aos maiores varejistas globais com atuação no setor alimentício (Walmart, Carrefour etc.), figurou como patrocinador oficial da Confederação Brasileira de Futebol (CBF) para divulgação das suas marcas na Copa do Mundo 2014, e atualmente apoia o Comitê Organizador dos Jogos Olímpicos Rio 2016, atletas e confederações esportivas. 
Segundo as informações prestadas pelos próprios imigrantes na chegada ao Acre, é elevado o percentual dos que não sabem exatamente para onde ir. Isso está plenamente de acordo com o fato de que a maioria permanece no acampamento, aguardando emprego e sem recursos para custear a própria viagem do Acre até os grandes centros. Em conformidade com o que foi anteriormente pontuado, com a documentação em mãos, os imigrantes aguardam com grande expectativa as empresas que se dirigem ao acampamento para recrutá-los e leválos ao Centro-Sul do país. Em casos mais esporádicos, quando eles recebem algum recurso enviado pela família, parentes ou amigos, conseguem organizar a partida do Acre por conta própria.

O perfil do estrangeiro recrutado pelas empresas é muito específico: homem, jovem, saudável, solteiro, sem filhos e com algum tipo de experiência laboral. Os imigrantes sem esse perfil têm mais dificuldades de recrutamento, como é o caso dos idosos, doentes e mulheres com filhos. No movimento de haitianos pela Amazônia acreana, os aspectos referentes à sua preparação como força de trabalho e contratação vêm revelando algumas características importantes sobre a seleção e a organização do trabalhador imigrante no Brasil. Por meio de entrevistas e conversas informais com os agentes da administração do acampamento, com representantes das empresas contratantes e com os próprios imigrantes, alguns dos contornos mais sutis desse movimento de trabalhadores são evidenciados.

De modo geral, o Ministério do Trabalho e Emprego e a Secretaria Geral da Presidência da República estabelecem redes de contatos com empresários para divulgar a disponibilidade de imigrantes no acampamento acreano, de acordo com o perfil dos cadastrados pela Secretaria de Direitos Humanos do Acre, incentivando a contratação desses trabalhadores (SEJUDH, 2013; TERRA, 2013). A partir de então, as empresas interessadas procuram a SEJUDH e a coordenação do acampamento, que se organizam para receber os agentes empresariais. $\mathrm{O}$ anúncio da chegada de uma firma no acampamento logo estimula os imigrantes, que prontamente se dispõem a participar dos processos de triagem realizados pelas empresas, pois isso os aproxima do sonho de começar a trabalhar e refazer a vida no Brasil.

Uma ou duas semanas após o contato institucional, os representantes da companhia chegam a Rio Branco e dirigem-se ao abrigo para organizar a triagem e a viagem do grupo selecionado. Em geral, a viagem é realizada em ônibus fretado, que vem da cidade de origem da empresa, apanha os imigrantes e retorna à sede da firma. Em situações que envolvem menor número de pessoas, a empresa e o coordenador do acampamento estabelecem uma espécie de acordo, a partir do qual ele fica encarregado de adquirir as passagens e embarcar os estrangeiros 
selecionados no aeroporto ou na rodoviária local, com destino à cidade-sede da firma. Já em casos de maior contingente recrutado, as empresas enviam uma equipe até a sede do acampamento, que improvisa uma espécie de escritório no interior do abrigo ou em área próxima, onde realiza a seleção criteriosa dos trabalhadores.

Ao longo dos últimos quatro anos, na maioria das vezes os agentes empresariais estiveram no Acre e organizaram uma estrutura para a triagem da força de trabalho na própria área do acampamento. Nessas ocasiões, os imigrantes adequados ao perfil "homem, jovem, saudável, solteiro, sem filhos e com algum tipo de experiência" formam longas filas e são, um a um, entrevistados pelos agentes. No processo de triagem se verifica, por exemplo, o porte físico do imigrante, buscando avaliar a espessura das suas mãos e pernas, o que indica, segundo o contratante, se a pessoa está ou não acostumada ao trabalho pesado. Também se observa a condição da pele e, em alguns casos, até a genitália do trabalhador, para identificar a presença ou não de hérnias, o que, de acordo com os avaliadores, pode expressar maior ou menor disposição física para a atividade braçal e pesada - ou mesmo inviabilizar a execução desse tipo de atividade.

A empresa pratica um contrato provisório pelo período de 45 dias com o imigrante, com remuneração de um salário mínimo mensal e possibilidade de renovação por mais 45 dias. Após esse período de 90 dias de experiência é que a empresa decide a permanência ou não do trabalhador no seu quadro funcional. Finalizada a seleção e organizada a viagem, eles partem nos ônibus fretados pelas empresas com destino aos seus futuros locais de trabalho. É importante ressaltar, ainda, que em muitos casos, na cidade onde vão se fixar, os imigrantes são alojados em uma residência administrada pela própria empresa, de maneira que a rotina de trabalho e vida do novo operário tende a ser ordenada e controlada diretamente.

Do sonho à realidade, após alguns anos de residência no Brasil, os relatos dos imigrantes sobre suas experiências revelam promessas não cumpridas sobre salários, alojamentos e condições de vida:

Uma empresa me levou do Acre ao Paraná, me prometendo quase $\mathrm{R} \$$ 900. Quando cheguei ao Paraná, o salário era menor. Com os descontos, dava só $\mathrm{R} \$$ 600. Isso não dava para comida e aluguel, e ainda tinha que mandar dinheiro para a minha filha no Haiti. $\mathrm{O}$ alojamento era sujo, camas quebraram, e a gente tinha que dormir no chão. [...] O pior lugar em que trabalhei foi o frigorífico. Ali aguentei só 45 dias. Fazia horas-extras, mas nunca recebi por elas. Em menos de dois meses, perdi dez quilos. Muitos colegas ficaram doentes, mas os frigoríficos não aceitam atestado e descontam o dia, se você vai ao médico. Então, os haitianos preferem cair no chão doentes no meio da fábrica a ir a um hospital (GEFFRARD, entrevista, 2014). 
Ao receber, abrigar, alimentar e documentar esses imigrantes, mesmo em condições precárias, como nos primeiros anos de acampamento, e considerando que o visto humanitário conferido aos haitianos é provisório, o Estado brasileiro pactua com o circuito estruturado de mobilidade do trabalho e acumulação de capital, mediante a exploração da força de trabalho imigrante (GAUDEMAR, 1979). Mesmo diante das inúmeras contradições do governo brasileiro no tratamento da questão, o circuito de serviços públicos moldado ao longo desses quatro anos de trânsito intenso e ininterrupto de imigrantes pela região, revela uma atuação do Estado como mediador necessário na organização da força de trabalho a ser oferecida a baixo custo ao capital.

\section{CONSIDERAÇÕES FINAIS}

O processo de reestruturação produtiva, deslanchado a partir da década de 1970, deu início a mudanças que redefiniram a forma como o capitalista regula, media e controla a produção de mais valia e a apropriação do trabalho excedente. Desde então, essa mutação produtiva em andamento teve amplas repercussões sobre a luta concorrencial, exigindo a renovação dos procedimentos para aprofundar a produção e a reprodução do capital, com a adoção de tecnologias e formas de gestão que, além de redefinir a relação entre empresas, impondo amplas cadeias de terceirizações, fechavam postos de trabalho e demitiam trabalhadores. Ademais, repercutiu também sobre a forma de reprodução da classe trabalhadora, inaugurando uma grande variedade de alternativas de venda e uso da força de trabalho, que restringiu o acesso ao emprego estável e ampliou o leque dos vínculos precários, com base no trabalho temporário, parcial, terceirizado e voluntário.

No contexto da mundialização do capital, notadamente após a eclosão da crise mundial de 2007-2008, inaugurou, ainda, novas modalidades de mobilidade do capital e da força de trabalho em diferentes partes do mundo. Tendo em vista o direcionamento da política humanitária de reconstrução do Haiti, que vem priorizando os interesses do capital industrial e financeiro, em detrimento das necessidades elementares da população local, a situação crítica no país impulsionou o crescente número de pessoas que se deslocam em direção ao Brasil, atraídos pelo "canto de sereia" das promessas de abertura de vagas de emprego nas obras da Copa do Mundo, Olimpíadas e no agronegócio de modo geral.

Assim, tornou-se necessário o debate sobre o movimento de trabalhadores e migração nacional e internacional, colocando no foco da discussão o exemplo 
histórico da migração haitiana, na sua passagem pela Amazônia Sul-Ocidental (estado do Acre), através da Rodovia Interoceânica, a partir de 2010. A realidade é que na Amazônia acreana vem se configurando uma espécie de mercado da força de trabalho pobre, negra e barata, com limitadas possibilidades de resistência às formas de exploração, opressão e violência que o trabalho precário estabelece. De um lado, registra-se, segundo o Observatório das Migrações Internacionais (OBMigra), vinculado ao MTE, que entre os anos de 2011 e 2013, o número de imigrantes no mercado de trabalho formal do país cresceu 50,9\%, sendo, atualmente, o Haiti a principal nacionalidade, uma vez que a população empregada de haitianos cresceu aproximadamente dezoito vezes, passando de 814 em 2011, para 14.579 em 2013. Por outro lado, crescem as denúncias e investigações de superexploração e trabalho escravo desses imigrantes no país. Dos casos mais recentes, três alçaram maior repercussão, a partir de ações que resultaram no resgate de 133 haitianos que trabalhavam para empresas de construção civil e têxteis (WROBLESKI, 2014a, 2014b).

Nesses casos, todos os 133 imigrantes libertados entraram no Brasil pela rota viabilizada pela Interoceânica até a Amazônia Ocidental, e passaram pelo acampamento instalado no Acre. Portanto, diante desse cenário, observa-se no Brasil a reedição do processo histórico imprescindível ao capitalismo mundial, que impõe aos Estados nacionais, políticas de reestruturação produtiva, contribuindo para a modelagem das correntes migratórias mundiais desenhadas pelos trabalhadores expropriados, em busca de novas possibilidades de sobrevivência. O debate está aberto e é necessário para acompanhar os desdobramentos do objeto de pesquisa e os desenhos dos movimentos dos trabalhadores na construção da história.

\section{REFERÊNCIAS}

\section{ACNUR-ALTO COMISSARIADO DAS NAÇÕES UNIDAS PARA}

REFUGIADOS. Refúgio no Brasil: uma análise estatística de janeiro de 2010 a outubro de 2014. Disponível em: < http:/ /www.acnur.org/t3/fileadmin/scripts/ doc.php?file =t3 / fileadmin/Documentos/portugues /Estatisticas / Refugio_no_ Brasil_2010_2014>.Acesso em: 10 nov. 2014.

ALMEIDA, E. Cartas do Haiti: relatos da situação num país em luta pela sua soberania. Resistir.info, Lisboa, 2 fev. 2010. Disponível em: <http://resistir. info/a_central/cartas_haiti.html> Acesso em: 15 ago. 2013. 
ALMEIDA, J. P. - Lógicas de reprodução social, trajetórias produtivas e gestão do meio natural entre agricultores familiares no sudoeste do Pará, Brasil. Novos Cadernos NAEA, Vol. 16, No 1 (2013), p. 149-172, jan-jun. 2013.

ALVES, G. O novo (e precário) mundo do trabalho. Reestruturação produtiva e crise do sindicalismo. São Paulo: Boitempo, 2000.

ANTUNES, R. (Org.). Riqueza e miséria do trabalho no Brasil. São Paulo: Boitempo, 2006.

Desenhando a nova morfologia do trabalho: as múltiplas formas de degradação do trabalho. Revista Crítica de Ciências Sociais, Lisboa, n. 83, 2008. Disponível em: <http://rccs.revues.org/431> Acesso em: 30 ago. 2013.

Os sentidos do trabalho: ensaio sobre a afirmação e negação do trabalho. São Paulo: Boitempo, 2009.

(Org.). Riqueza e miséria do trabalho no Brasil II. São Paulo: Boitempo, 2013.

ARRUDA, I. Na periferia da alagação. Jornal A Gazeta. Rio Branco (AC), 16 mar. 2014. Acre Economia. Suplemento.

BÄCHTOLD, F. Frio senegalês: cidades do interior gaúcho recebem onda de migração do país africano; senegaleses afirmam que a população é solidária. Folha de São Paulo. São Paulo, 14 dez. 2013. Disponível em: <http://www1. folha.uol.com.br/fsp/mundo/143688-frio-senegales.shtml> Acesso em: 20 dez. 2013.

BAENINGER, R.; ANTICO, C. Questões decorentes da emergência da migração internacional no Brasil. In: PATARRA, N. L. (Org.). Migrações internacionais: herança XX, agenda XXI. Campinas: FUNAP, 1996. v. 2, p. 259-268.

BASSO, P. Imigração na Europa. In: ANTUNES, R. (Org.). Riqueza e miséria do trabalho no Brasil II. São Paulo: Boitempo, 2013. p. 29-53.

BIDEGAIN, G. A donde va el área metropolitana de Puerto Prínce, después del sismo: entre el sueño y la realidad. In: CONGRESO DA ASOCIACIÓN LATINOAMERICANA DE POBLACIÓN-ALAP, 4, 2010, Havana. Anais... Havana: ALAP, 2010.

BORGES, D. Damião Borges: depoimento [set. 2013]. Entrevistadores: Letícia Helena Mamed e Eurenice Oliveira de Lima. Brasiléia, 2013. 1 arquivo mp3 (20 min.). Entrevista concedida ao Projeto de Pesquisa Trabalho e Migração Internacional: O Caso dos Haitianos na Amazônia Ocidental. 
BRITO, S. Ocupação do Haiti é agressão imperialista. A nova democracia, Rio de Janeiro, fev. 2009. Disponível em: <http://www.anovademocracia.com.br/ no-50/2040-ocupacao-do-haiti-e-agressao-imperialista $>$ Acesso em: 15 ago. 2013.

CARREIRO, M. Brasil no Haiti: o desastre da Minustah. Revista Eletrônica Tempo Presente, Rio de Janeiro, ano 4, n. 2, 2009.

CASTLES, S. Globalização, transnacionalismo e novos fluxos migratórios dos trabalhadores convidados às migrações globais. Lisboa: Fim de Século, 2005.

CAVALCANTI, L.; OLIVEIRA, A. T.; TONHATI, T. (Orgs.). A inserção dos imigrantes no mercado de trabalho brasileiro. Brasília: OBMigra, 2014. (Cadernos do Observatório das Migrações Internacionais)

CEPAL-COMISSÃO ECONÔMICA PARA AMÉRICA LATINA E CARIBE -. La migración internacional en América Latina y el Caribe: tendencias y perfiles de los migrantes. Santiago, 2006. Disponível em: <http://www.eclac. cl/celade/default.asp>. Acesso em: 13 ago. 2013.

CHERISNORD, L. Haiti: quatro anos após o terremoto, nada mudou (Especial Minustah-10 Anos). Carta Capital, São Paulo, 11 ago. 2014. Entrevista concedida a Marsílea Gombata.

CHESNAIS, François. A mundialização do capital. São Paulo: Xamã, 1996.

CHOSSUDOVSKY, M. Globalização da pobreza e a nova ordem mundial. 2003. Lisboa: Caminho, 2003.

Raízes históricas da crise social no Brasil - o papel do FMI. Resistir. info, Portugal, 21 jun. 2013. Disponível em: <http:/ / resistir.info/chossudovsky/ brasil_21jun13.html> Acesso em: 15 ago. 2013.

COGGIOLA, O. Haiti: terremoto, colonização e resistência. O Olho da História, Salvador, n. 14, jun. 2010. Disponível em: <http://oolhodahistoria. org/n14/artigos/coggiola.pdf> Acesso em: 15 jan. 2014.

COSTA, Pe. G. A. Haitianos em Manaus: dois anos de imigração - e agora! Travessia - Revista do Migrante, ano XXV, n. 70, p. 91-98, jan./jun. 2012. Disponível em: <http://www.youblisher.com/p/550077-Travessia-Revista-doMigrante-numero-70/>. Acesso em: 10 out. 2013.

CUNHA, D. M. C.; CUNHA, R. F. As falácias do modelo de integração regional e comercial: desnudando os interesses da IIRSA na fronteira amazônica. In: 
SEMINÁRIO INTERNACIONAL - AMAZÔNIA E FRONTEIRAS DO CONHECIMENTO, 2008, Belém. Anais... Belém: UFPA, 2008. Disponível em: <http://www2.ufpa.br/naea/ siteNaea35/anais/html/geraCapa/FINAL/ GT8-144-1153-20081204101052.pdf>. Acesso em: 5 jul. 2013.

DELVA, J. G. Novo parque industrial deve criar milhares de empregos no Haiti. Reuters Brasil. São Paulo, 29 nov. 2011. Disponível em: <http://br.reuters. com/article/worldNews/ idBRSPE7AS02G20111129> Acesso em: 10 mar. 2014.

DELGADO, N. G. - Agronegócio e agricultura familiar no Brasil: desafios para a transformação democrática no meio rural. Novos Cadernos NAEA, v. 15, n. 1, p. 85-129, jan-jun. 2012, NAEA/UDPA, Belem, 2012.

DIEESE-DEPARTAMENTO INTERSINDICAL DE ESTATÍSTICA E ESTUDOS SOCIOECONÔMICOS. Rotatividade e flexibilidade no mercado de trabalho. São Paulo: DIEESE, 2011.

DRUCK, G. A precarização social do trabalho no Brasil. In: ANTUNES, R. (Org.). Riqueza e miséria do trabalho no Brasil II. São Paulo: Boitempo, 2013. p. 55-73.

ENGELS, F. A situação da classe trabalhadora na Inglaterra. São Paulo: Boitempo, 2008.

FERRAZ, L. Rede de coiotes controla tráfico de haitianos ao país. Folha de São Paulo, São Paulo, 27 maio 2014. Disponível em: <http:/ /www1.folha.uol.com. br/ cotidiano/2014/05/1460493-rede-de-coiotes-controla-trafico-de-haitianosao-pais.shtml>. Acesso em: 30 maio 2014.

FERNANDES, D. (Coord.). Estudos sobre a migração haitiana ao Brasil e diálogo bilateral. Relatório final de pesquisa. Belo Horizonte: Grupo de Estudos Distribuição Espacial da População, Pontifícia Universidade Católica de Minas Gerais, Ministério do Trabalho e Emprego, Organização Internacional para Migração, 2014.

FERNANDES, D.; MILESI, R.; FARIAS, A. Do Haiti para o Brasil: o novo fluxo migratório. Instituto Migrações e Direitos Humanos, 20 jan. 2014. Disponível em: <http://www.migrante.org.br/migrante/index.php?option=com_content\& view $=$ article $\&$ id $=214$ :do-haiti-para-o-brasil-o-novo-fluxo-migratorio $\&$ catid $=89$ \&Itemid=1210> . Acesso em: 20 fev. 2014. 
FERNANDES, J. S. Operação Haiti: ação humanitária ou interesse político para o Brasil?. Conjuntura Internacional, n. 22, p. 1-3, mar. 2010. (Série Cenários PUC Minas). Disponível em: <http://www.pucmg.br/imagedb/conjuntura/ CNO_ARQ_NOTIC20100323112219.pdf>. Acesso em: 10 abr. 2012.

FILGUEIRAS, V. Trabalho análogo ao escravo e o limite da relação de emprego: natureza e disputa na regulação do Estado. Brasiliana - Journal for Brazilian Studies, v. 2, n.2, p. 187-218. out. 2013.

ENGELS, F. A situação da classe trabalhadora na Inglaterra. São Paulo: Boitempo, 2008.

ESQUIVEL, M. Petrocaribe: integração energética de novo tipo. Prensa Latina, 1 dez. 2014. Disponível em: <http://m.vermelho.org.br/noticia/petrocaribe_ integracao_energetica_de_novo_tipo/254479-7>. Acesso em: 5 dez. 2014.

FRESNILLO, I. Haiti, quatro anos depois do terremoto: a miragem da reconstrução. Revista Fórum, São Paulo, v. 130, 16 jan. 2014. Disponível em: $<$ http://revistaforum.com.br/digital/130/haiti-quatro-anos-depois-terremotomiragem-da-reconstrucao/> Acesso em: 20 jan. 2014.

GAlEANO, E. Os pecados do Haiti. Carta Maior, São Paulo, 19 jan. 2010. Disponível em: <http://www.cartamaior.com.br/templates/materiaMostrar. cfm?materia_id=16342> Acesso em: 15 ago. 2013.

GEFFRARD, M. Imigrantes haitianos e africanos são explorados em carvoarias e frigoríficos. O Globo, Rio de Janeiro, 17 ago. 2014. Entrevista concedida a Mariana Sanches.

GLASS, V. Com ajuda do Brasil, Haiti pode virar maquiladora, diz ativista. Carta Maior, São Paulo, 2 ago. 2004. Disponível em: < http://www.cartamaior.com. br/templates/materiaMostrar.cfm?materia_id=2442> Acesso em: 15 ago. 2013.

GOMBATA, M. Haiti - 10 anos de Minustah. Carta Capital, São Paulo, 11 ago. 2014. Disponível em: <http://www.cartacapital.com.br/autores/haiti/>. Acesso em: 30 ago. 2014.

GORENDER, J. O épico e o trágico na história do Haiti. Estudos Avançados, São Paulo, v. 24, n. 3, p. 483-512, 2004.

GAUDEMAR, J-P de. Movilidad del trabajo y acumulación de capital. México: Era, 1979.

HALLWARD, P. Opção zero no Haiti. In: SADER, E. (Org.). Contragolpes. Tradução de New Left Review.São Paulo: Boitempo, 2006. p. 219-242. 
HARVEY, D. Condição pós-moderna: pesquisa sobre as origens da mudança cultural. São Paulo: Loyola, 2002.

O novo imperialismo. São Paulo: Loyola, 2004.

O enigma do capital: e as crises do capitalismo. São Paulo: Boitempo, 2011.

HATIAN DIASPORA. Disponível em: < http://haitiandiaspora.com>. Acesso em: 30 dez. 2011.

HUNTINGTON, S. O choque das civilizações. São Paulo: Objetiva, 1997.

IBGE-INSTITUTO BRASILEIRO DE GEOGRAFIA E ESTATÍSTICA.

Indicadores. Disponível em: <http://www.ibge.gov.br/home/mapa_site/ mapa_site.php $>$ Acesso em: 15 out. 2013.

JACKSON, R. Geographies of the Haitian diaspora. New York: Routledge, 2013.

JAMES, C. L. R. Os jacobinos negros. São Paulo: Boitempo, 2000.

MACHADO, A. Haitianos relatam que encontraram corpos em decomposição durante fuga para o Brasil, diz antropóloga. Terra Magazine - Blog da Amazônia, São Paulo, 5 jan. 2012. Disponível em: <http://terramagazine. terra.com.br/blogdaamazonia/blog/2012/01/05/haitianos-relatam-queencontraram-corpos-em-decomposicao-durante-fuga-para-o-brasil-dizantropologa/> Acesso em: 10 ago. 2013.

Acre prorroga situação de emergência por causa de haitianos. Terra Magazine - Blog da Amazônia. São Paulo, 17 jan. 2014a. Disponível em: <http://terramagazine.terra.com.br/blogdaamazonia/blog/2014/01/17/acreprorroga-situacao-de-emergencia-por-causa-de-haitianos/> Acesso em: 20 jan. 2014.

Isolamento do Acre deixa mais de 1300 haitianos e senegaleses retidos em abrigo na fronteira. Terra Magazine - Blog da Amazônia. São Paulo, 28 fev. 2014b. Disponível em: <http://terramagazine.terra.com.br/blogdaamazonia/ blog/2014/02/28/isolamento-do-acre-deixa-mais-de-1300-haitianos-esenegaleses-retidos-em-abrigo-na-fronteira/> Acesso em: 2 mar. 2014.

Acre quer aviões da FAB para remover haitianos de seu território. Terra Magazine - Blog da Amazônia. São Paulo, 28 mar. 2014c. Disponível em: <http://terramagazine.terra.com.br/blogdaamazonia/blog/2014/03/28/ acre-quer-avioes-da-fab-para-remover-haitianos-de-seu-territorio/> Acesso em: 29 mar. 2014. 
Acre quer que governo federal assuma abrigo de imigrantes. Terra Magazine - Blog da Amazônia. São Paulo, 26 dez. 2014d. Disponível em: $<$ http://noticias.terra.com.br/brasil/blogdaamazonia/blog/2014/12/26/acrequer-que-governo-federal-assuma-abrigo-de-imigrantes/>. Acesso em: 26 dez. 2014.

MALDONADO, R.; BAJUK, N.; HAYEM, M. Las remesas a América Latina y el Caribe durante el 2011: recuperando el crecimiento. Washington: Fondo Multilateral de Inversiones, Banco Interamericano de Desarrollo, 2012.

MAMED, L. H.; LIMA, E. O. de. Precarização estrutural e migração internacional de trabalhadores: a problemática dos haitianos na Amazônia. In: CONGRESSO BRASILEIRO DE SOCIOLOGIA, 16, 2013, Salvador. Anais.... Salvador: SBS, 2013a.

Trabalho e Migração Internacional: o caso dos haitianos na Amazônia Ocidental. In: CONGRESO LATINOAMERICANO DE SOCIOLOGÍA-ALAS, 29., 2013, Santiago. Anais... Santiago: ALAS, 2013 b.

Movimento internacional de trabalhadores haitianos: da passagem pela Amazônia ao Trabalho no Centro-Sul do Brasil. In: CONGRESO LATINOAMERICANO DE SOCIOLOGÍA RURAL - ALASRU, 9, 2014, Cidade do México, Anais... Cidade do México: ALASRU, 2014.

Trabalho, Precarização, Migração e Recrutamento de Haitianos na Amazônia pela Agroindústria da Carne. In: ENCONTRO DA REDE DE ESTUDOS RURAIS - DESIGUALDADE, EXCLUSÃO E CONFLITOS NOS ESPAÇOS RURAIS, 4, 2014, Campinas. Anais... Campinas: Rede de Estudos Rurais, 2014.

MARX, K. O capital. Livro I. São Paulo: Nova Cultural, 1985.

TEM-MINISTÉRIO DO TRABALHO E EMPREGO; CNIG-CONSELHO NACIONAL DE IMIGRAÇÃO. Resolução Normativa n ${ }^{\circ} \mathbf{9 7}$ - Dispõe sobre a concessão do visto permanente previsto no art. 16 da Lei no 6.815, de 19 de agosto de 1980, a nacionais do Haiti. Brasília: 12 jan. 2012, Disponível em: <http:// portal.mte.gov.br/data/files/8A7C816A350AC8820135687F345B412D/ RESOLU\%C3\%87\%C3\%83O\%20NORMATIVA\%20N\%C2\%BA\%2097. pdf>. Acesso em: 10 out. 2014.

MTE-MINISTÉRIO DO TRABALHO E EMPREGO; CONSELHO NACIONAL DE IMIGRAÇÃO, INSTITUTO MIGRAÇÕES E DIREITOS HUMANOS, COMPANHIA DE JESUS. Guia de informações sobre trabalho aos haitianos. Brasília: [s.ed.], 2012. 
MORAES, I. A.; ANDRADE, C. A. A. de; MATTOS, B. R. B. Imigração haitiana para o Brasil: causas e desafios. Revista Conjuntura Austral, v. 4, n. 20, p. 95114, out./nov. 2013.

NELI, M. A.; NAVARRO, V. L. Reestruturação produtiva e saúde do trabalhador na agroindústria avícola no Brasil. In: ANTUNES, R. (Org.). Riqueza e miséria do trabalho no Brasil II. São Paulo: Boitempo, 2013. p. 287-304.

PATARRA, N. L. Migrações internacionais de e para o Brasil contemporâneo: volumes, fluxos, significados e políticas. São Paulo Perspectiva, v. 19, n. 03, p. 23-33, set. 2006.

PAULA, E. A. de. Entre desastres e transgressões. A chegada dos imigrantes haitianos no "Reino deste mundo Amazônico". Novos Cardernos NAEA, Belém, v. 16, n. 2, p. 187-206, dez. 2013.

PORISSAINT, F. Haiti: quatro anos após o terremoto, nada mudou (Especial Minustah-10 Anos). Carta Capital, São Paulo, 11 ago. 2014. Entrevista concedida a Marsílea Gombata.

PRIMI, L. Índios na linha de produção. Caros Amigos, São Paulo, n. 197, p. 20-23, ago. 2013.

REPÓRTER BRASIL. Moendo Gente: a situação do trabalho nos frigoríficos. São Paulo: [s.n.], 2013. Disponível em: <http://www.escravonempensar.org. br/wpcontent/uploads/2013/03/ upfilesfolder_materiais_arquivos_moendo_ gente_final.pdf>. Acesso em: 30 ago. 2013.

ROBIOU, C. Haiti: quatro anos após o terremoto, nada mudou (Especial Minustah-10 Anos). Carta Capital, São Paulo, 11 ago. 2014. Entrevista concedida a Marsílea Gombata.

ROUSSEAU, J. H. Haiti: quince años no son nada, pero se avanza em población y desarrollo. In: CONGRESO DA ASOCIACIÓN LATINOAMERICANA DE POBLACIÓN, 4, 2010, Havana. Anais... Havana: ALAP, 2010.

SADER, E.; JINKINGS, I.; MARTINS, C. E.; NOBILE, R. (Coords.). Latinoamericana: Enciclopédia Contemporânea da América Latina e do Caribe. São Paulo: Boitempo, 2006.

SASSEN, S. Dos enclaves en las geografías globales contemporáneas del trabajo. In: ARAGONÉS, A. M. (Coord.). Mercado de trabajo y migracíón internacional. México: UNAM; Instituto de Investigaciones Económicas, 2011. p. 139-194. 
SECRETARIA DE DIREITOS HUMANOS DA PRESIDENNCIA DA REPÚBLICA. Resultado da Aplicação do Questionário sobre a Situação dos/as Migrantes e/ou Solicitantes de Refúgio no Abrigo de Brasiléia/ AC - para uso interno do Serviço Público Federal. Brasilia: SDH/PR, 2014.

SEDS-SECRETARIA DE ESTADO DE DESENVOLVIMENTO SOCIAL. Relatório anual parcial de atendimento humanitário aos imigrantes presentes no Estado do Acre. Rio Branco: SEDS, 2014.

SEJUDH-SECRETARIA DE ESTADO DE JUSTIÇA E DIREITOS HUMANOS. Relatório situacional de atendimento humanitário aos imigrantes presentes no Estado do Acre. Rio Branco: SEJUDH, 2013.

Relatório situacional de atendimento humanitário aos imigrantes presentes no Estado do Acre. Rio Branco: SEJUDH, 2014.

SEGUY, F. O Haiti é aqui e lá. Jornal da APUG. Fundação Lauro Campos, Belém, 1 mar. 2010. Disponível em: <http://laurocampos.org.br/2010/03/ohaiti-e-aqui-e-la/> Acesso em: 20 mar. 2014.

A catástrofe de janeiro de 2010, a "Internacional Comunitária" e a recolonização do Haiti. 2014. 2014. Tese (Doutorado em Sociologia) Instituto de Filosofia e Ciências Humanas, Universidade Estadual de Campinas, Campinas, 2014.

SILVA, S. A. da. Brazil, a new eldorado for immigrants? The case of haitians and the brazilian immigration policy. Urbanities, v. 3, n. 2, nov. 2013. Disponível em: <http://www.anthrojournalurbanities.com/docs/ tableofcontents_5/2Sidney $\% 20$ Antonio $\% 20 \mathrm{da} \% 20$ Silva.pdf $>$. Acesso em: 10 dez. 2013.

SÔNEGO, D. Brasil já recebe menos dinheiro de emigrantes que o Haiti. País foi o único da América Latina e Caribe a ter queda no volume de recursos enviados por seus cidadãos no exterior, em 2011. Portal IG, São Paulo, 14 mar. 2012. Disponível em: <http://economia.ig.com.br/brasil-ja-recebe-menos-dinheirode-imigrantes-que-o-haiti/n1597692787307.html> Acesso em: 13 ago. 2013.

STOCHERO, T. Sonho brasileiro aquece comércio de documentos e vistos falsos no Haiti. Portal G1, São Paulo, 18 out. 2013. Disponível em: <http:// g1.globo.com/mundo/noticia/2013/10/sonho-brasileiro-aquece-comercio-dedocumentos-e-vistos-falsos-no-haiti.html> Acesso em: 30 out. 2013. 
TÉLÉMAQUE, J. Imigração haitiana na mídia brasileira: entre fatos e representações. 2012. 95f. Monografia (Bacharelado em Comunicação Social, habilitação em Publicidade e Propaganda) - Escola de Comunicação, Universidade Federal do Rio de Janeiro, Rio de Janeiro, 2012.

TERMÉUS, T. Haiti: quatro anos após o terremoto, nada mudou (Especial Minustah-10 Anos). Carta Capital, São Paulo, 11 ago. 2014. Entrevista concedida a Marsílea Gombata.

TERRA. Imigrantes haitianos recebem vacinas e carteiras de trabalho no Acre. São Paulo, 16 abr. 2013. Disponível em: <http://noticias.terra.com.br/ brasil/imigrantes-haitianos-recebem-vacinas-e-carteiras-de-trabalho-no-acre, 7 bc3d0283e41e310VgnVCM5000009ccceb0aRCRD.html> Acesso em: 30 out. 2013.

VILBRUN, W. Entrevista I: depoimento [set. 2013]. Entrevistadores: Letícia Helena Mamed e Eurenice Oliveira de Lima. Brasiléia, 2013. 1 arquivo mp3 (10 min.). Entrevista concedida ao Projeto de Pesquisa Trabalho e Migração Internacional: O Caso dos Haitianos na Amazônia Ocidental.

VILLELA, H. Gastos da ONU no Haiti pagariam mais de 100 hospitais. Portal Vermelho, São Paulo, 7 fev. 2012. Disponível em: <http://www.vermelho.org. br/noticia/175055-7>. Acesso em: 30 out. 2014.

VILLEN, P. Polarização do mercado de trabalho e a nova imigração internacional no Brasil. In: SEMINÁRIO DO TRABALHO: TRABALHO E POLÍTICAS SOCIAIS NO SÉCULO XXI, 8., 2012, Marília. Anais... Marília: Unesp, 2012. Disponível em: <http://www.estudosdotrabalho.org/texto/gt5/polarizacao. pdf> Acesso em: 30 ago. 2013

WROBLESKI, S. Imigrantes haitianos são escravizados no Brasil. Repórter Brasil, São Paulo, 23 jan. 2014a. Disponível em: < http://reporterbrasil.org. br/2014/01/imigrantes-haitianos-sao-escravizados-no-brasil/> Acesso em: 30 jan. 2014.

Fiscalização resgata haitianos escravizados em oficina de costura em São Paulo. Repórter Brasil, São Paulo, 22 ago. 2014b. Disponível em: < http:// reporterbrasil.org.br/2014/08/ fiscalizacao-resgata-haitianos-escravizados-emoficina-de-costura-em-sao-paulo/> Acesso em: 30 ago. 2014. 